\title{
Soporte. El uso del dinero como material en las artes visuales. Support. Money as Material in Visual Arts
}

\section{BORISONIK, Hernán}

Miño y Dávila editores, Buenos Aires, 2017

ISBN: 978-987-42-4946-3

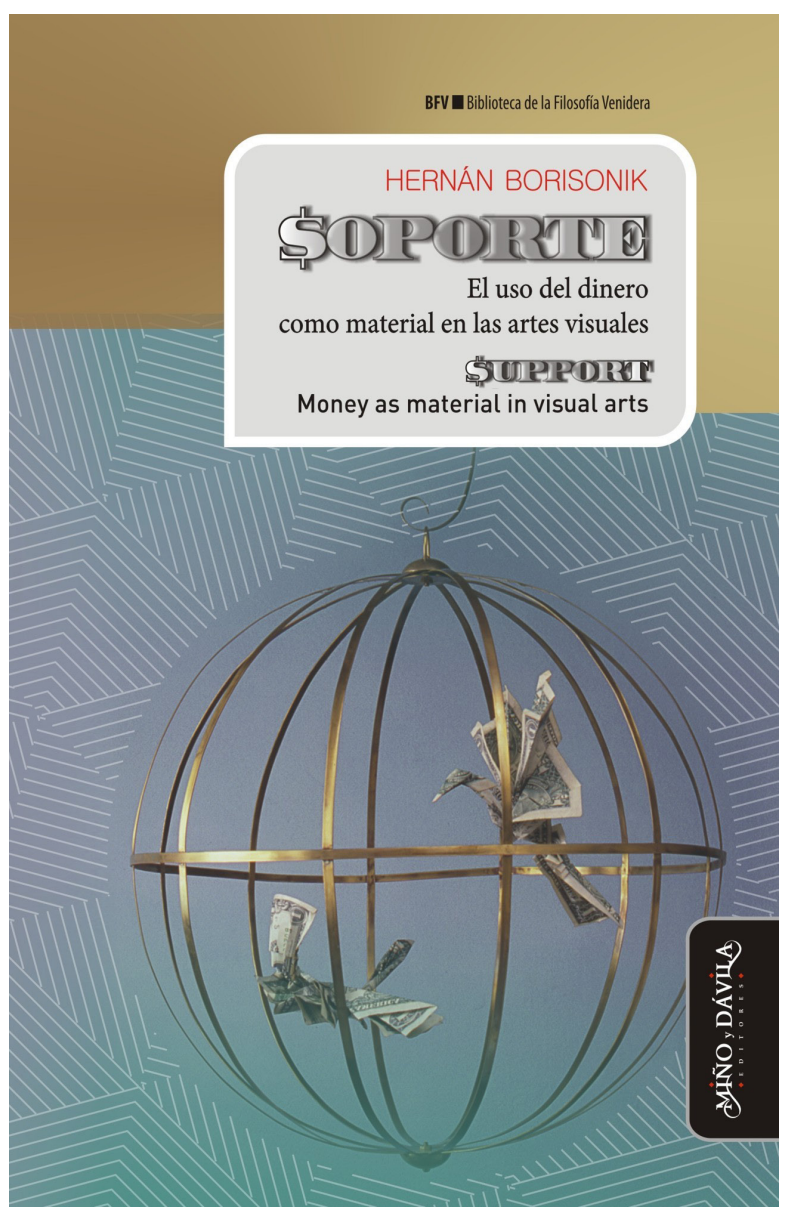

Los estudios sobre las relaciones entre dinero y obras de arte han estado asociados a la sociología del arte o la sociología del mercado. A contrapelo de esa tendencia, el libro de Hernán Borisonik (un doctor en ciencias sociales, especializado en filosofía política clásica) se interna en el mundo de la plástica para plantear una hipótesis bastante concreta: el uso del dinero en obras de arte tiene un potencial emancipador. A partir de esa idea, pero echando mano de herramientas más teóricas que de casos concretos, lleva adelante un estudio sobre el dinero a lo largo de un mapa en el que dibuja algunos problemas actuales en perspectiva transdisciplinaria, con foco en el campo de las artes visuales.

Lejos de buscar una genealogía del uso "crítico-artístico» del dinero, el trabajo de Borisonik atina a enhebrar algo del momento histórico actual en su especificidad (por ejemplo, frente a lo que llama «la internetización de la vida») con hilos conceptuales. Así, se inserta en (y dialoga con) una línea muy poco transitada (y mucho menos en lengua castellana) a la que pertenecen, por un lado, Marc Shell, Johan Holten o Max Haiven y, por el otro, una serie de fuentes filosóficas clásicas, encabezadas sin duda por Aristóteles (pensador que constituía el centro del libro anterior de este autor) y que incluyen a Karl Marx y Friedrich Nietzsche. Pero dado que, como el propio Borisonik afirma, la reflexión sobre el dinero no puede ser abordada desde un solo punto de vista, el texto se deja influenciar por las reflexiones de Aby Warburg, Walter Benjamin y Georg Simmel, pero también por el psicoanálisis, Giorgio Agamben y Boris Groys, entre otros.

El índice de este ensayo académico recorre ocho breves estaciones que incluyen, además de las imágenes y reflexiones sobre arte contemporáneo, un homenaje a JeanLuc Godard, una historia conceptual del dinero, una delicada tesis sobre el fetichismo más allá de los límites del capitalismo y, sobre todo, un compendio algo desordenado de pensamientos sobre las subjetividades que produce el acceso al mundo a través de imágenes reproducidas (y muchas veces también creadas) en pantallas digitales. El texto nos recuerda que en las prácticas conceptualistas de la década de 1960 (que fueron luego consideradas por varios teóricos como el origen del camino hacia el arte digital), se produjo un viraje de la atención hacia lo inmaterial como un objeto de estudio, pero también como elemento clave para comprender la realidad concreta (individual y también colectiva). Frente a eso, el autor deja planteados algunos interrogantes que resuenan permanentemente en nuestros tiempos: ¿se puede pensar 
aún en el arte (más allá de ser considerado en algunos ámbitos como un mero objeto de consumo) como un ámbito válido para buscar la verdad (¿y qué es la verdad?)?; ¿cuánta divergencia es sostenible entre un planeta finito y un dinero infinito?; ¿es el carácter nominal (conceptual) del dinero contemporáneo lo que facilita su uso acumulativo en desmedro de otras personas?; ¿cómo se vincula esa forma conceptual con el arte literal de nuestros días?

De lectura fluida y relativamente accesible a un gran público, el libro funciona como un disparador ingenioso para pensar diferentes aristas que hacen al arte contemporáneo, como la portabilidad de las obras digitales (en sintonía con la movilidad absoluta del dinero electrónico) o la preeminencia en muchos casos de las biografías de los artistas por sobre la sensibilidad de sus obras (cuestión que atiende a una mercantilización más veloz y sencilla). Pero, como el propio autor subraya, su intención no es encontrar respuestas, sino abrir un campo de estudios transdisciplinarios que logre comprender el peso y significado de lo medial, cuestión que deja abierta para futuras contribuciones.

El volumen (bilingüe, castellano/inglés, pero que también ha sido traducido al portugués en 2019 en Brasil) cuenta con la muy cuidada edición de Miño y Dávila (editorial con bases en Madrid y en Buenos Aires) y obtuvo el apoyo de
«Mecenazgo cultural» de Argentina. Asimismo, incluye varias obras referidas a las cuestiones analizadas, que acompañan armónicamente los textos, entre las que se destacan Balance económico de Jaime Pitarch, Novo Coin de Carla Cruz y Antonio Contador, Amor, Ordem e Progresso. Projeto de Arte Financeira de Lourival Cuquinha, Más dinero con dinero de Esteban Álvarez, Three Thousand US Dollar Bills to Takeaway de Cesare Pietroiusti y Chirolas, Exacción, Excedente de Cristina Piffer.

Acompañan al texto principal un lúcido prólogo de Florencia Qualina y cuatro «apéndices» (de María Stegmayer, Federico Baeza, Álvaro Cifuentes y Tamara Stuby -autora de la obra de tapa-) que ilustran algunos de las cuestiones tratadas por Borisonik con ejemplos de las artes visuales en Argentina.

En resumen, una propuesta poco usual, muy rica en aportes en el campo del pensamiento contemporáneo, que, desde una perspectiva que involucra al arte, la filosofía y las ciencias sociales, nos propone detenernos a contemplar la realidad antes de utilizar automáticamente algunas categorías heredadas de la tradición y volver a vincular al arte con la posibilidad de una acción que exceda su propio campo.

Juan Acerbi

Universidad Nacional de Tierra del Fuego 